\title{
POPULATION FLUCTUATIONS OF LEPUS FLAVIGULARIS (LAGOMORPHA: LEPORIDAE) AT TEHUANTEPEC ISTHMUS, OAXACA, MEXICO
}

\author{
Consuelo Lorenzo'1, Tamara M. RIOJA ${ }^{1}$, Arturo CARRILlo ${ }^{1}$ \\ y Fernando A. Cervantes 2
}

${ }^{1}$ El Colegio de la Frontera Sur, Departamento de Ecología y Sistemática Terrestres, Carretera Panamericana y Periférico Sur s/n, San Cristóbal de Las Casas, Chiapas. 29290, MÉXICO

E-mail: clorenzo@ecosur.mx, trioja@ecosur.mx; acarrillo@ecosur.mx 2Departamento de Zoología, Instituto de Biología, Universidad Nacional Autónoma de México, Coyoacán, México, Distrito Federal. 04510, MÉXICO fac@ibiologia.unam.mx

\section{RESUMEN}

Se analizaron datos sobre densidad poblacional de la liebre de Tehuantepec, Lepus flavigularis durante seis años de monitoreo en las poblaciones de Montecillo Santa Cruz y San Francisco del Mar Viejo, al sur del Istmo de Tehuantepec, Oaxaca, México. Se calculó el índice de fluctuación poblacional (IF) para esta especie de lagomorfo en las dos localidades. Los intervalos en fluctuación entre niveles poblacionales máximos y mínimos fueron evaluados de acuerdo al número promedio de años requeridos para que los cambios ocurran. Se llevó a cabo el método de transecto de ancho fijo para la obtención de valores de densidad. La liebre de Tehuantepec presenta en general, valores en densidad bajos en ambas poblaciones de estudio, con IF altos en Montecillo Santa Cruz, lo que indica que presenta una gran amplitud de cambios en su tamaño poblacional en periodos de tiempo cortos, debido probablemente a las prácticas de uso de suelo de la zona, mismas que incluyen una intensa ganadería extensiva y la aplicación de quemas controladas. En San Francisco del Mar Viejo, zona con menor intensidad de pastoreo y sin quemas, la liebre de Tehuantepec presentó valores de IF bajos, por lo que es probable que en esta población la especie se mantenga más estable a lo largo del tiempo.

Palabras Clave: fluctuación poblacional, lagomorfo, Lepus flavigularis, Istmo de Tehuantepec, Oaxaca, México.

\begin{abstract}
Through six years Lepus flavigularis population density data were analyzed, at two localities south Tehuantepec Isthmus, Oaxaca, Mexico. The fluctuation index (FI) was calculated for this lagomorph in two localities. FI refers to ranges in fluctuations between maximum and minimum population levels evaluated according to the average number of years required for the changes to take place. Density was obtained by the fixed-width transect method. Lepus flavigularis exhibited low density values in both populations. High FI values in Montecillo Santa Cruz indicate high amplitude of change in population's size in a short period of time. This probably caused by extensive grazing and prescribed burnings. In
\end{abstract}


San Francisco del Mar Viejo L. flavigularis exhibited low FI values, indicating low population changes over the same period of time. This probably because there is slight grazing and no prescribed burns.

Key Words: population fluctuation, lagomorph, Lepus flavigularis, Tehuantepec Isthmus, Oaxaca, Mexico.

\section{INTRODUCTION}

Habitat disturbance and fragmentation is increasing in Mexico (Instituto Nacional de Ecología 2000). Like result, a wide number of species is in danger of extinction, including some lagomorphs in small and highly vulnerable isolated populations (Cervantes et al. 1990, Cervantes \& González 1996, Cervantes et al. 1997). Just in Mexico, 15 species of lagomorphs are distributed, divided in three genuses. Inside these, there is the Tehuantepec jackrabbit, Lepus flavigularis. The Tehuantepec jackrabbit is an endemic species of the south Tehuantepec Isthmus, Oaxaca (Anderson \& Gaunt 1962), being the only species of American jackrabbits that lives in tropical zones, with a distribution of $150 \mathrm{~km}^{2}$ in the surroundings of the Isthmus (López-Forment 1989). The Mexican government declared this species of high priority in the conservation due to the restricted distribution of its habitat and to its excessive hunting (Instituto Nacional de Ecología 1997, SEMARNAT 2002). This jackrabbit is considered the most threatened of the world (Chapman et al. 1990, Flux \& Angermann 1990, Cervantes 1993, Baillie \& Groombridge 1996).

The populations of this species undergo serious threats, mainly by human activities (Portales et al. 1997, Lorenzo et al. 2000). It's necessary to have more biological information of Lepus flavigularis, with the purpose of establishing efficient management and conservation programs in the future. One of the aspects that should be evaluated is the population fluctuation of this species. The abundance and the density of the populations are fundamental parameters in the decisions making for the management and conservation of wildlife (Caughley 1977). The density is the representation of the population abundance of a species, and it's product of the balance between populations parameters such like natality, mortality, and immigration and emigration (Galindo-Leal 1999). The habitat conditions have a great influence in the lagomorphs densities, as the amount and quality of available food (Bronson \& Tiemeier 1959, Daniel et al. 1993), including those cases in which the habitat conditions are altered by its modification or degradation (Vorhies \& Taylor 1933, Flinders \& Hansen 1975, Sullivan \& Moses 1986, Tapper \& Barnes 1986).

These factors provoke population fluctuations in several taxa through the time, which have been considered as cycles related with regulative phenomenons or like answers to the environmental changes (Keith \& Windberg 1978, Keith 1990), as well as caused by complex interactions between the lagomorphs and the plants with which they feed and between these and their predators (Erlinge et al. 1984, Bailey 2005). 
Such cycles in the population density of some mammals are clearly defined, just like happens for Lepus americanus, whose interval of duration is of eight to ten years, period during which there are population peaks and declines related basically with the supply of food, predation and the leveret survival. Also, the population cycles of this species in Canada and Alaska affects to more than one species; during the population peaks, the jackrabbits could compete with the elks for the food and directly affect the lynx population density, its almost exclusive predator (Gobierno de Yukon 2005). In the same way, the population density of European rabbits (Oryctolagus cuniculus) in Canarias, Spain, presents clear variations along the year, the maximum values take place in late spring when the juveniles are incorporated to the population, and abruptly descend in summer, at the beginning of the hunting season and irruption of sickness (Gobierno de Canarias 2005).

There're very few studies of the population density of $L$. flavigularis and there're no research about population fluctuation neither how this is related to the habitat changes. For L. flavigularis has been reported densities between 6 and 13 individuals $/ \mathrm{km}^{2}$ (Lorenzo et al. 2000, Vargas 2000, Sántiz 2002, Farías 2004). In the study area, this lagomorph share its habitat with other species of mammals like the eastern cottontail (Sylvilagus floridanus), the hooded skunk (Mephitis macroura), the coyote (Canis latrans), and the gray fox (Urocyon cinereoargenteus) (Lorenzo et a l.2000, Farías 2004). There are no studies about the populations fluctuations of these in the area of study. In this study the fluctuation index was used, it refers to ranges in fluctuations between maximum and minimum population levels evaluated according to the average number of years required for the changes to take place (Terman 1966).

Due to the importance of knowledge on density fluctuations of the lagomorphs to long term, the objectives of this study were: 1) to know the density fluctuation of the Tehuantepec jackrabbit Lepus flavigularis in two populations through six years; 2) to compare the population densities fluctuations through the fluctuation index; and 3) to determine possible relationships between the population densities fluctuations and the land use changes during the period of study.

\section{MATERIAL AND METHODS}

Study area. This study was conducted at localities of Montecillo Santa Cruz $\left(16^{\circ} 22^{\prime} 05^{\prime}\right.$ 'N, 94³5'15.4”W) and San Francisco del Mar Viejo (16¹3'58.2”N, 94³7'56.3”W), south Tehuantepec Isthmus, Oaxaca, Mexico; in the Municipality of San Francisco del Mar (Fig. 1). Study area is located at northeast Istmica-Chiapaneca coastal plain, which is situated between Sierra Madre de Chiapas and Pacific Ocean (Zizumbo \& Colunga 1982). Climate is tropical with mean annual temperature of $27.6^{\circ} \mathrm{C}$, mean annual rainfall of $800 \mathrm{~mm}$ (Instituto Nacional de Estadística Geografía e Informática 1995), and 
marked seasons. The rainy season is from May to October with an intra-estival drought in August, and the dry season is from November to April and is severe during late winter and early spring (Zizumbo \& Colunga 1982). The sampled area size comprised $43.8 \mathrm{~km}^{2}$ in Montecillo Santa Cruz, and 7.6 km² in San Francisco del Mar Viejo.

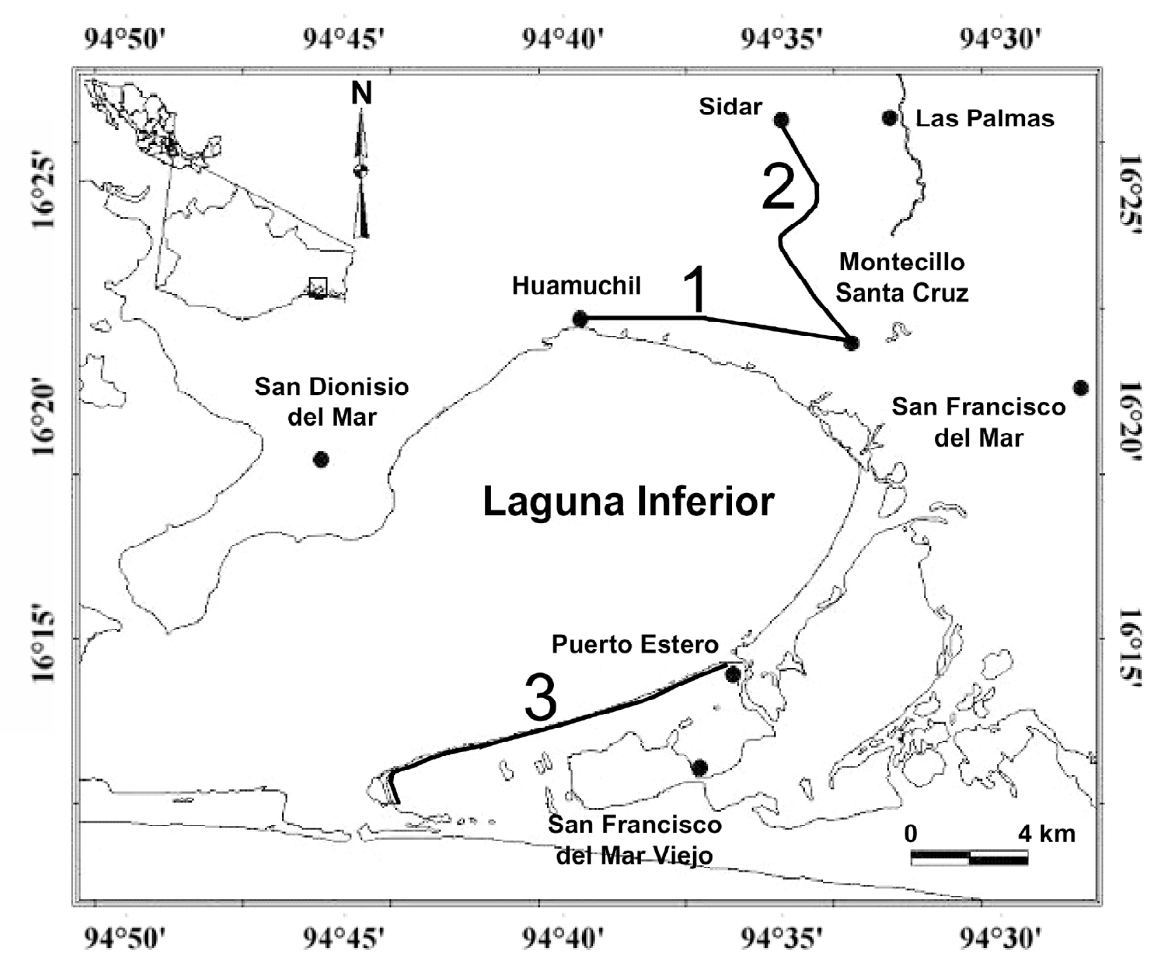

Figure 1

Transects established for studying the density of medium mammals in Montecillo Santa Cruz (1 and 2) and San Francisco del Mar Viejo (3), Municipality of San Francisco del Mar, Oaxaca, Mexico, during 2001 to 2006.

Vegetation. Four habitat types were identified in Montecillo Santa Cruz: 1) grassland: open and plain areas, tending to flood during wet season, characterized by a forbs stratum compound by grasses, herbs, and some "morro" trees (Crescentia alata) and shrubs. Commonest species are the grasses Aristida sp. and Trisetum sp.; 2) nanchal: semi open areas compound mainly by forbs and shrubs stratums; shrubs density is higher than grassland and the predominant species is the "nanche" (Byrsonima crassifolia); 3) shrub: close areas, compound by thorny and deciduous shrubs and trees with 4 meters high. Commonest species are Acacia farnesiana, Casearia sp., and Aristida sp.; 4) riparian vegetation: little patches compound by 
dense vegetation growing in streams margins. It's characterized by very high deciduous trees (15 meters high). Aristida sp., Gliricidia sepium and Celtis iguanaea are characteristic (Pérez-García et al. 2001, Farías 2004, Sántiz 2005).

In San Francisco del Mar Viejo characteristic habitat is coastal vegetation. Forbs are predominant and there are some mangrove swamps around ponds and estuaries (Salas 2003). There is thorny deciduous low tropical forest neighboring with coastal dunes. Acacia spp. and some Cactaceae species are predominant (Sántiz 2002).

Land use. The residents of Montecillo Santa Cruz are traditional fishermen, although in the last years the agriculture has become an important activity for the generation of basic products (Vargas 2001). There are also other activities like the trade, the cattle raising, and the hunt in minor proportion. In Montecillo Santa Cruz extensive cattle raising is carried out in the whole zone of grassland, and the practices of prescribed burnings are habitual in order to promote the grass regeneration. In San Francisco del Mar Viejo the main activity is the fishing, which constitute a widespread activity and it's also the base of a distinctive economy. In the surroundings of the town is carried out the extensive cattle raising (Gómez 2005).

Using 2000 and 2003 satellite images (LANDSAT ETM, $30 \mathrm{~m}$ per pixel space resolution, six available bands, path 23, row 49), an analysis was carried out in order to determine: 1) the types of vegetation associated with the sample transects and, 2) the extension of burn zones due to the area management practices.

Density estimation. The values of density were obtained during a period of six years, from 2001 until 2006 along the dry and rainy seasons. Three lineal fixed width transects were established by their accessibility (acceptable roads for to use vehicles) and visibility for detecting mammals species in the night (with open flat areas), two in Montecillo Santa Cruz ( $7 \mathrm{~km}$ and $8 \mathrm{~km}$ longitude), and one in San Francisco del Mar Viejo (14 km longitude, Fig.1). Number of observed individuals was registered using lighthouses of halogen and a pick up vehicle at speed of $5-10 \mathrm{~km} / \mathrm{h}$ along of transects. The width of the transects was fixed in 70 meters to each side by the maximum potency of light of the spotlights, and therefore, the maximum distance which was possible to distinguish the presence of jackrabbits. Transects were traveled every night in a round trip, recording every jackrabbit observed; for to calculate values of density, we considered only the route with the highest number of individuals observed. The geographical position, altitude and habitat type of each individual observed was recorded.

The annual mean density of Lepus flavigularis was obtained dividing the average in the number of individuals observed by the sampled area size (modified from Davis \& Winstead 1987, Mandujano \& Aranda 1993, Mandujano 1994), according with the formula:

$$
\mathrm{D}=\frac{\mathrm{N}}{\mathrm{WL}}
$$

Where: $\mathrm{D}=$ annual mean density; $\mathrm{N}=$ average in the number of individuals observed $\mathrm{W}=$ width of transects; $\mathrm{L}=$ large of transects 
The density obtained correspond to area of transects studied (total area studied in each jackrabbit locations). Estimated population size of L. flavigularis was obtained using density data, and approximate distribution area, calculated by the total area occupied by the species through of registers of each jackrabbit observed from 2001 to 2006 in two populations. The study area was divided into $1 \mathrm{~km}^{2}$ units. The location of each individual was obtained with a Geographical Positioning System unit and recorded in a spreadsheet. Data were exported to ArcView software 3.2a for to project and visualize them in a satellite image of 2003 (LANDSAT ETM).

Where:

$$
\mathrm{P}=\mathrm{D} * \mathrm{~A}
$$

$$
\begin{aligned}
& \mathrm{P}=\text { population size } \\
& \mathrm{D}=\text { annual mean density } \\
& \mathrm{A}=\text { distribution area }\left(\mathrm{km}^{2}\right)
\end{aligned}
$$

Population Fluctuation Index estimation. Maximum and minimum intervals in population densities fluctuation was referred as the Fluctuation Index (FI) by Terman (1966). It was calculated using relationship between the mean range of populations fluctuations for the species and the mean time (years) for these changes to occur.

$\mathrm{FI}=$ Mean range of population fluctuations/Mean years for range to occur

Statistical analysis. Comparison of population densities between the two populations was carried out using t Student significance tests (STATISTICA '98, Statsoft 1998). The analysis of the satellite images was carried out using the ArcView software 3.2a, and the extensions Spatial Analyst 2.0 and Image Analyst 1.0 (Environmental Systems Research Institute Inc., Redlands, CA.)

\section{RESULTS}

Registered mammals. Besides lagomorph L. flavigularis, we observed diverse species of medium mammals: eastern cottontail (S. floridanus), nine banded armadillo (Dasypus novemcinctus), common opossum (Didelphis sp.), gray fox (U. cinereoargenteus), coyote (C. latrans), raccoon (Procyon lotor), and skunks (Conepatus leuconotus, M. macroura and Spilogale putorius). Also in some zones (at the foot of some hills), was observed white tailed deer (Odocoileus virginianus). Bovine and equine livestock were frequently observed in grasslands and along sample transects, as well as domestic cats and dogs in the localities nearest zones. 
Densities. In Montecillo Santa Cruz, annual mean density of Tehuantepec jackrabbit was 4.32 individuals $/ \mathrm{km}^{2}$ (Standard Deviation=1.10). Estimated population size of L. flavigularis was 189.23 individuals. Annual mean density fluctuation is showed in Figure 2. Lepus flavigularis showed a density decreasing tendency from 2000 to 2006, in spite of two increments in 2004 and 2006 (Fig. 2).

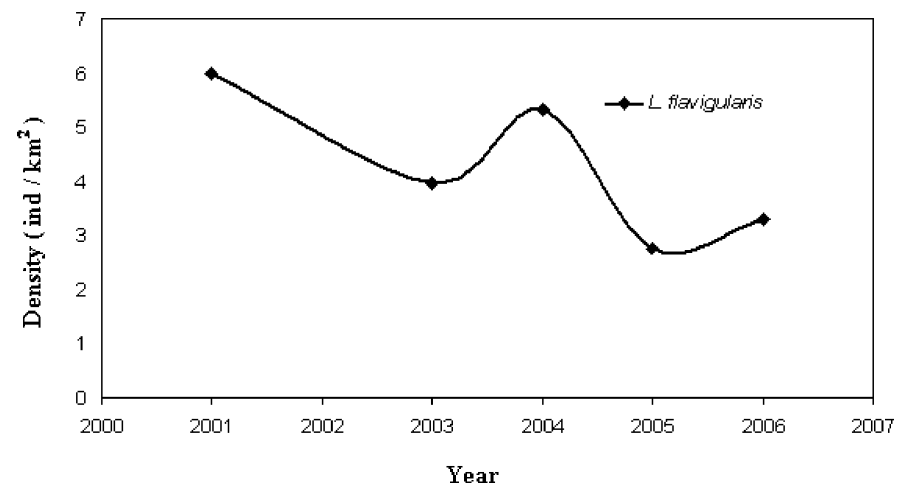

Figure 2

Population fluctuation of Tehuantepec jackrabbit (Lepus flavigularis) in Montecillo Santa Cruz, Municipality of San Francisco del Mar, Oaxaca, Mexico, during 2001 to 2006.

In San Francisco del Mar Viejo, annual mean density for Tehuantepec jackrabbit was 5.38 individuals $/ \mathrm{km}^{2}$ (Standard Deviation=0.91). Estimated population size of L. flavigularis was 40.92 individuals. Annual mean density fluctuation is showed in Figure 3.

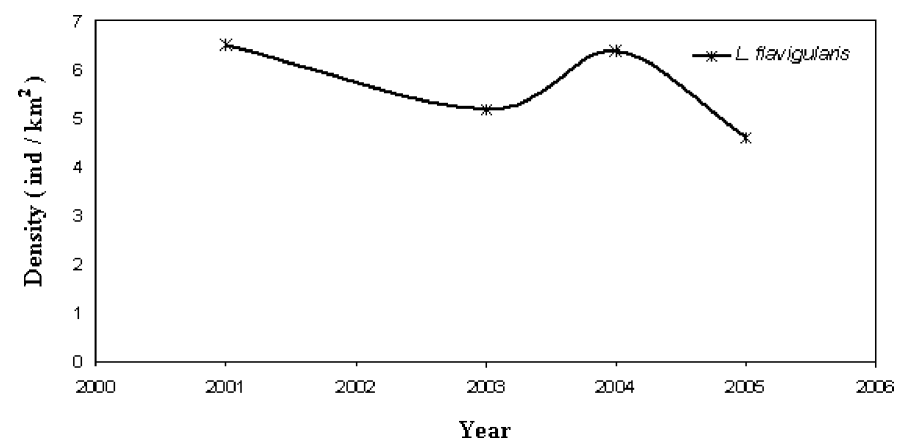

Figure 3

Population fluctuation of Tehuantepec jackrabbit (Lepus flavigularis) in San Francisco del Mar Viejo, Municipality of San Francisco del Mar, Oaxaca, Mexico, during 2001 to 2005.

A t-Student test showed that was not a significant difference between population densities of Montecillo Santa Cruz and San Francisco del Mar Viejo $(\mathrm{t}=-2.05$, $\mathrm{p}=0.1087$, marked differences at $\mathrm{p}<0.05000$ ). 
a)

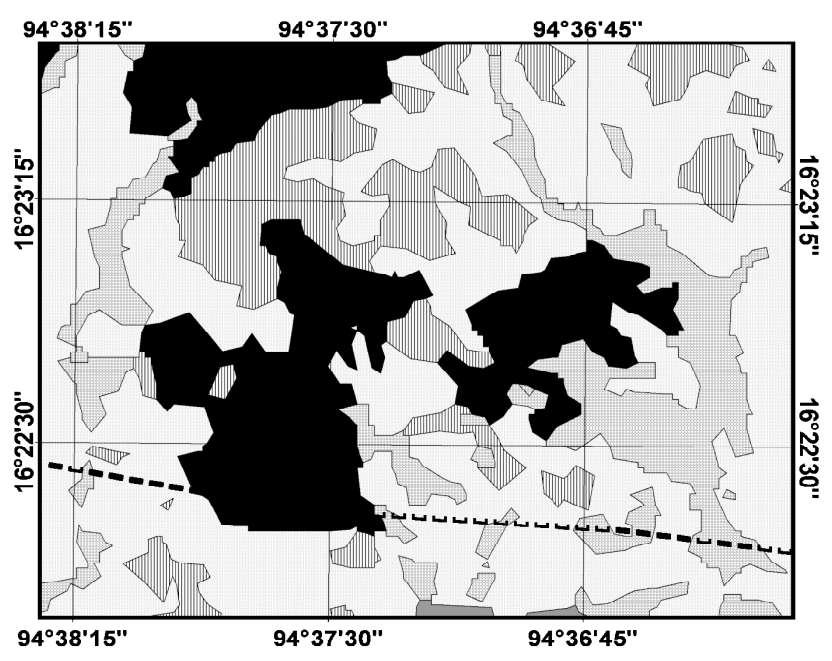

b)

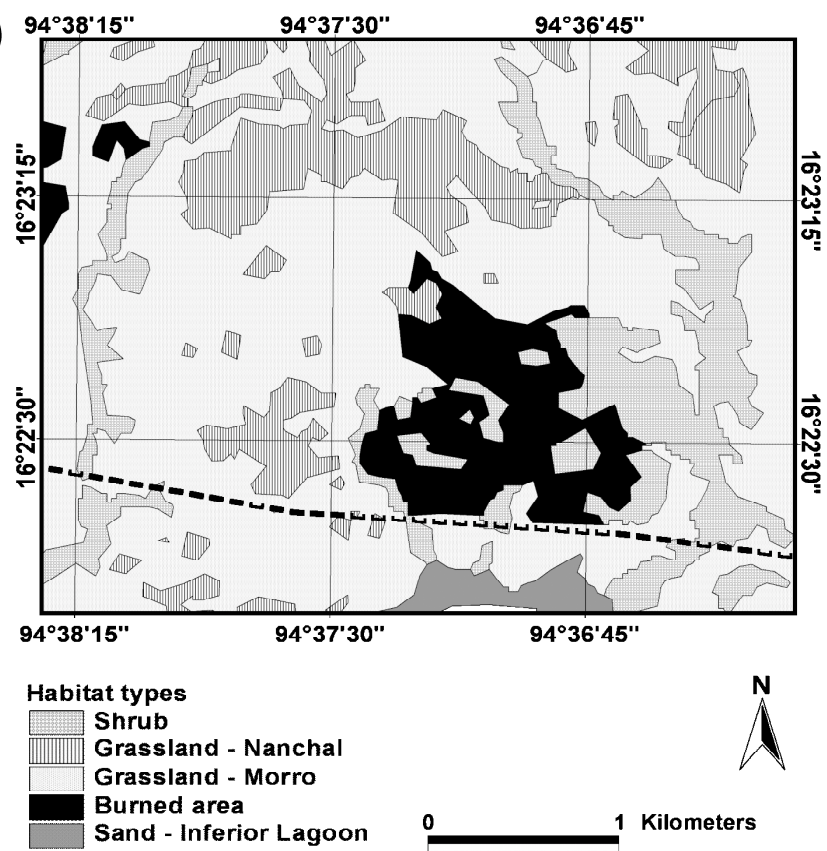

Figure 4

Habitat types with burned areas in black, during a) 2000 and b) 2003 in Montecillo Santa Cruz, Municipality of San Francisco del Mar, Oaxaca, Mexico. Discontinuous lines correspond to one part of transect established in this locality. 
Fluctuation Index. FI value was highly different between two populations. In Montecillo Santa Cruz, L. flavigularis showed a FI of 42.99 and in San Francisco del Mar Viejo, L. flavigularis showed a FI of 5.165.

Part of the vegetation in Montecillo Santa Cruz was burned. The prescribed burning was part of the management practices of grazing area, which consist of the provocation of fires in order to promote the regeneration of the grassland during the dry season. These fires frequently become uncontrolled, which affect to extensive areas in region. During the years 2000 and 2003, 19.88\% and $8.54 \%$ of the surface was affected for the fire, respectively (Fig. 4). In contrast, along this investigation in San Francisco del Mar locality burned areas were not observed.

\section{DISCUSSION}

In the two localities, L. flavigularis presented low mean density values if compared with other lagomorph species. In northwest Mexico (Valley of Santo Domingo, Baja California Sur), densities of L. californicus were evaluated in order to determine the damage that it causes to chickpea cultivation, registering densities of 2 and 11 individuals $/ \mathrm{km}^{2}$ (Rodriguez \& Arnaud 1990). In Nevada, L. californicus showed densities of 20 individuals $/ \mathrm{km}^{2}$ (Hayden 1966), and up to 3,500 individuals $/ \mathrm{km}^{2}$ (14 jackrabbits per acre) in Kansas, in winter months, where the animals were forced to concentrate in crop fields to obtain food and suitable habitat, due to droughts and overgrazing (Bronson \& Tiemeier 1959). In Texas, similarly, this species showed densities of 154 individuals $/ \mathrm{km}^{2}$ due to overgrazing (Davis \& Schmidly 1997).

In United States, S. floridanus showed densities from 310 individuals $/ \mathrm{km}^{2}$ (3.1 individuals/ha) up to 2,000 individuals $/ \mathrm{km}^{2}$ (20 individuals/ha) (Chapman et al. 1982); however, in the province of Alessandria, northwest Italy, the maximum densities values in this species were of 25 individuals $/ \mathrm{km}^{2}$ to 27.5 individuals $/ \mathrm{km}^{2}$ ( 2.5 to 2.75 individuals/10 ha) (Silvano et al. 2000). Sylvilagus aquaticus showed fall densities of 40 individuals $/ \mathrm{km}^{2}(0.4$ individuals $/ \mathrm{ha})$ in Indiana, and $S$. nuttallii showed wide fluctuations of 6 individuals $/ \mathrm{km}^{2}$ (0.06 individuals $\left./ \mathrm{ha}\right)$ to 250 individuals $/ \mathrm{km}^{2}$ (2.5 individuals/ha) in Oregon (Chapman et al. 1982).

By the other hand, Vargas (2000) registered density values of L. flavigularis of 11.5 individuals $/ \mathrm{km}^{2}$ in an area of $1.3 \mathrm{~km}^{2}$, as well as 3.9 individuals $/ \mathrm{km}^{2}$ in an area of $1.8 \mathrm{~km}^{2}$ in a population located between Santa Maria del Mar and San Mateo del Mar, Oaxaca. Sántiz (2002) reports density values of L. flavigularis of 6.0 and 6.5 individuals $/ \mathrm{km}^{2}$ in Montecillo Santa Cruz and San Francisco del Mar Viejo, respectively. The low density values of this lagomorph species resulted in population mean size very low, which should take in bill in specific actions for the conservation 
of these species. Habitat alteration and degradation probably occasioned a decrease in food and space availability, resulting in low population densities (Lorenzo et al. 2000, Sántiz 2002). Daniel et al. (1993) report a similar effect on L. californicus at the Chihuahuense Desert, where density values were higher in habitat with better conditions of food and protection. This suggestion is also supported for Sullivan \& Moses (1986), who registered a dramatic decrease in density of L. americanus in degraded areas in The British Columbia.

It's very interesting notice that Lepus flavigularis showed FI values minor in San Francisco del Mar Viejo than in Montecillo Santa Cruz, this means that Tehuantepec jackrabbit population stay more stable along time in San Francisco del Mar Viejo. Seemingly this could be conditioned by the different land use practices, since in Montecillo Santa Cruz grassland areas were observed subjected to fire and grazing, while in San Francisco del Mar Viejo, prescribed burning is not present, and grazing intensity is minor. Through the satellite images analysis we observed that burned areas were more extensive in 2000 than 2003 in Montecillo Santa Cruz, which could it be reflected in the lower population density in 2003 and the increase in jackrabbit population densities in the 2004; this seems to indicate that this species doesn't use recently burned areas. This observation is supported by reports like that of Meslow \& Keith (1968), who founded that L. americanus recolonize a burned area three years after the fire occurred, even there are registrations of recolonization up to 6 to 7 years after the fire (Burgason 1977). This depends on the time in which habitat recovers their capacity to provide enough food and protection to the lagomorphs (Parker 1984).

Of great importance for conservation actions is that prescribed burns are carried out every year, with the purpose of promoting grasslands regeneration for the livestock; these burns frequently are left from control and they extend to very extensive zones. Probably that burns intensity doesn't permit the lagomorphs reestablishment in burned areas (Driessen 1999, Salvatori et al. 2001). Also, burned areas break habitat temporarily into fragments, this could affect the densities and populations size of diverse species (Fahrig \& Paloheimo 1988, Diffendorfer et al. 1995, Klok \& DeRoos 1998), as well as the populations dynamic (Hassell 1980, Stamps et al. 1987).

Our results indicate that L. flavigularis densities in Montecillo Santa Cruz and San Francisco del Mar Viejo localities are low in comparison with other lagomorphs species, which places them in a situation of risk with regard to their conservation. Area management practices like the use of prescribed burns in Montecillo Santa Cruz, seems to influence directly in population fluctuations of this species of lagomorph, and could cause abrupt changes in their densities in short periods of time.

The present study is the first in their type that includes data about population changes in a long term for the highest extinction treat lagomorph species, $L$. 
flavigularis. This study will be of great utility for future studies concerning management and conservation of this species and its habitat. It's important remark that it is necessary carry out detailed studies about relationship of this lagomorph with other mammals and with diverse variables like grazing, prescribed burns, as well as rainfall, temperature and changes in land use.

\section{ACKNOWLEDGMENTS}

We thank Miguel Aquino, Roberto Gutiérrez, Leyberto Gutiérrez, Juan Antonio, Jorge Bolaños, Eugenia Sántiz, Julieta Vargas, Felipe Barragán, and the Municipalities of San Francisco del Mar for their valuable help during field work. The families Antonio Gutiérrez and Gutiérrez Vázquez housed our crew. Chicago Zoological Society, Lincoln Park Zoo Neotropic Fund, Consejo Nacional de Ciencia y Tecnología, and Secretaría de Medio Ambiente y Recursos Naturales, partly funded this research. Two anonymous reviewers provided valuable comments on several drafts of the manuscript.

\section{LITERATURE CITED}

Anderson, S. \& A. Gaunt. 1962. A classification of the white-sided jackrabbits of Mexico. Amer. Mus. Novitates 2088:1-16.

Baillie, J. \& B. Groombridge. 1996. 1996 IUCN Red list of threatened animals. IUCN, Gland, Switzerland.

Bailey, T. 2005. Peninsula snowshoe hares on the decline. Kenai National Wildlife Refuge. Refuge Notebook. U. S. Fish \& Wildlife Service, Alaska.

Bronson, F.H. \& O.W. Tiemeier. 1959. The relationship of precipitation and black tailed jackrabbit populations in Kansas. Ecology 40:194-198.

Burgason, R.N. 1977. Bird and mammal use of old age commercial clear-cuts in northern Maine. Thesis, University of Maine.

Caughley, G. 1977. Analysis of vertebrate populations. John Wiley \& Sons, New York.

Cervantes, F.A. 1993. Lepus flavigularis. Mamm. Species 423:1-3.

Cervantes, F.A. \& F. González. 1996. Los conejos y liebres silvestres de Mexico. Pp. 17-25. In: A. Velásquez, F. J. Romero and J. López (eds). Ecología y conservación del conejo zacatuche y su hábitat. Universidad Nacional Autónoma de México, Fondo de Cultura Económica, México.

Cervantes, F.A., C. Lorenzo \& M. Engstrom. 1997. New records of the eastern cottontail (Sylvilagus floridanus) and black tailed jack rabbit (Lepus californicus) in Mexico. Texas J. Sci. 49:75-77.

Cervantes, F.A., C. Lorenzo \& R.S. Hoffman. 1990. Romerolagus diazi. Mamm. Species 360:1-7.

Chapman, J.A., J. Hockman \& W. Edwards. 1982. Cottontails (Sylvilagus floridanus) and Allies. Pp. 83-123. In: J. A. Chapman and G. A. Feldhamer (eds). Wild Mammals of North America. Johns Hopkins, Baltimore. 
Chapman, J.A., J.E.C. Flux, A.T. Smith, D.J. Bell, G.G. Ceballos, K.R. Dixon, F.C. Dobler, N.A. Formozov, R.K. Ghose, W.L.R. Oliver, T. Robinson, E. Schneider, S.S. Stuart, K. Sugimurua, \& Z. Changlin. 1990. Chapter 14: Conservation action needed for rabbits, hares, and pikas. Pp. 154-168. In: J.A. Chapman and J.E.C. Flux (eds). Rabbits, hares, and pikas. Status survey and conservation action plan. International Union for Conservation of Nature and Natural Resources. Gland, Switzerland.

Daniel, A., J. Holechek, R. Valdez, A. Tembo, L. Saiwana, M. Fusco \& M. Cardenas. 1993. Jackrabbit densities on fair and good condition Chihuahuan desert range. J. Range Mgmt. 46:524-528.

Davis, E. \& L. Winstead. 1987. Estimación de tamaños de poblaciones de vida silvestre. Pp. 233-258. In: R. Rodriguez (ed). Manual de Técnicas de Gestión de Vida Silvestre. The Wildlife Society, Washington, D. C.

Davis, B. \& D. J. Schmidly. 1997. Black-tailed Jackrabbit. The Mammals of Texas - Online Edition. Texas Tech University. http://www.nsrl.ttu.edu/tmot1/Default.htm

Diffendorfer, J.E., M.S. Gaines \& R.D. Holt. 1995. Habitat fragmentation and movements of three small mammals (Sigmodon, Microtus and Peromyscus). Ecology 76:827-839.

Driessen, M. 1999. Effects of fire on the broad-toothed mouse, Mastacomys fuscus, and other small mammals in buttongrass moorlands of western Tasmania - preliminary findings. Conference Proceedings. Australian Bushfire Conference, Albury.

Erlinge, S., G. Göransson, G. Högstedt, G. Jansson, O. Liberg, J. Loman, I. N. Nilsson, T. Von Schantz \& M. Sylven. 1984. Can Vertebrate Predators Regulate they Prey?. Amer. Nat. 123:125-133.

Fahrig, L. \& J. Paloheimo. 1988. Determinants of local population size in patchy environments. Theoretical Population Biol. 34:194-213.

Farías, V. 2004. Spatio-temporal ecology and habitat selection of the critically endangered tropical hare (Lepus flavigularis) in Oaxaca, Mexico. Ph.D. dissertation, Massachusetts University.

Flinders, J.T. \& R.M. Hansen. 1975. Spring population responses of cottontails and jackrabbits to cattle grazing short-grass prairie. J. Range Mgmt. 28:290-293.

Flux, J.E.C. \& R. Angermann. 1990. The hares and jackrabbits. Pp. 61-94. In: J.A. Chapman and J.E.C. Flux (eds). Rabbits, hares and pikas. Status survey and Conservation Action Plan. International Union for the Conservation of Nature and Natural Resources. Gland, Switzerland.

Galindo-Leal, C. 1999. Monitoreo Biológico. Pp. 9-17. In: A. Carr III y A.C. Stoll. (eds). Monitoreo Biológico en la Selva Maya. US Man and the Biosphere Program/Tropical Ecosystem Directorate and Wildlife Conservation Society.

Gobierno de Canarias. 2005. Manual del Cazador. Conserjería de Medio. Ambiente y Ordenación Territorial. http://www.gobiernodecanarias.org/cmayot/servlet/ViewDocu? id_documento $=1107 \&$ id_pagina $=16$.

Gobierno de Yukon. 2005. Snowshoe hare. Environmental department. http://www.environmentyukon.gov.yk.ca/snhare.html

Gómez, A. 2005. Variación genética intrapoblacional de la liebre del Istmo, Lepus flavigularis (Mammalia:Lagomorpha) en San Francisco del Mar Pueblo Viejo, Oaxaca, 
México. Tesis de licenciatura, Universidad de Ciencias y Artes de Chiapas, Chiapas, México.

Hassell, M.P. 1980. Some consequences of habitat heterogeneity for population dynamics. Oikos 35:150-160.

Hayden, P. 1966. Seasonal occurrence of jackrabbits on Jackass Flat, Nevada. J. Wildl. Mgmt. 30:835-838.

Instituto Nacional de Ecología. 1997. Programa de Conservación de la Vida Silvestre y Diversificación Productiva en el Sector Rural. 1997-2000 México. Secretaría de Medio Ambiente, Recursos Naturales y Pesca, Instituto Nacional de Ecología, México.

Instituto Nacional de Ecología. 2000. Estrategia Nacional para la Vida Silvestre. Logros y retos para el Desarrollo Sustentable. Dirección General de Vida Silvestre. Secretaria de Medio Ambiente, Recursos Naturales y Pesca.

Instituto Nacional de Estadística, Geografía e Informática. 1995. Marco geoestadístico. Dirección General de Geografia del Territorio Nacional. INEGI. Mexico.

Keith, L. 1990. Dynamics of snowshoe hare populations. Pp. 119-195. In: H. H. Genoways (ed). Current Mammalogy. Plenum Press, New York.

Keith, L.B. \& L.A. Windberg. 1978. A demographic analysis of the snowshoe hare cycle. Wildl. Monogr. 58:1-70.

Klok, C. \& A.M. DeRoos. 1998. Effects of habitat size and quality on equilibrium density and extinction time of Sorex araneus populations. J. Anim. Ecol. 67:195-209.

Lorenzo, C., O. Retana Guiascon, F. A. Cervantes, J. Vargas \& G. L. Portales. 2000. Status survey of the critically endangered Lepus flavigularis. Final report to Chicago Zoological Society, El Colegio de la Frontera Sur. San Cristóbal de Las Casas, Chiapas, Mexico.

López-Forment, W. 1989. News of Lepus flavigularis. Lagomorph Newsl. 9:4.

Mandujano, S. \& M. Aranda. 1993. Conteo de venados Odocoileus virginianus (CERVIDAE), en transectos: recomendaciones para su aplicación. Biotam 5:43-46.

Mandujano, S. 1994. Conceptos generales del método de conteo de animales en transectos. Ciencia 45:203-211.

Meslow, E.C. \& L.B. Keith. 1968. Demographic parameters of snowshoe hare population. J. Wildl. Mgmt. 32:812-834.

Parker, G.R. 1984. Use of spruce plantations by snowshoe hare in New Brunswick. Forestry Chronicle 60:162-166.

Pérez-García, E., J. Meave \& C. Gallardo. 2001. Vegetación y flora de la región de Nizanda, Istmo de Tehuantepec, Oaxaca, México. Acta Bot. Mex. 56:19-88.

Portales, G.L., P. Reyes, H. Rangel, A. Velásquez, P. Millar, S. Ellis \& A. Smith. 1997. Taller Internacional para la Conservación de los lagomorfos mexicanos en Peligro de Extinción. Reporte del Taller. IUCN/SSC Conservation Breeding Specialist Group. Apple Valley, Minnesota.

Rodriguez, J. \& G. Arnaud. 1990. Densidad de la liebre cola negra (Lepus californicus) en el Valle de Santo Domingo, Baja California Sur. Pp. 421-429. In: Memorias del VIII Simposio sobre Fauna Silvestre. Facultad de Medicina Veterinaria y Zootecnia, 
Universidad Nacional Autónoma de México y Asociación de Zoológicos, Criaderos y Acuarios de la República Mexicana. México.

Salas, M.S.H. 2003. La flora de las selvas caducifolias de Zimatan, costa Oaxaca. Sociedad Botánica de México, México.

Salvatori, V., F. Egunyu, A.K. Skidmore, J. de Leeuw \& H.A.M. Van Gils. 2001. The effects of fire and grazing pressure on vegetation cover and small mammal populations in the Maasai Mara National Reserve. African J. Ecol. 39:200-204.

Sántiz, L. E. 2002. Distribución y abundancia de la liebre endémica Lepus flavigularis y el conejo castellano Sylvilagus floridanus (Mammalia: Lagomorpha) en el Istmo de Tehuantepec, Oaxaca, México. Tesis de licenciatura, Universidad de Ciencias y Artes de Chiapas.

Sántiz, L. E. 2005. Selección de hábitat y densidad de la liebre del Istmo Lepus flavigularis (Wagner 1844) en Oaxaca, México. Tesis de maestría, Instituto de Ecología, A.C.

SEMARNAT, 2002. Norma Oficial Mexicana NOM-059-ECOL-2001, Protección

Ambiental-Especies nativas de México de flora y fauna silvestres-Categorías de riesgo y especificaciones para su inclusión, exclusión o cambio-Lista de especies en riesgo. Diario Oficial de la Federación. 1-80.

Silvano, F., C. Acquarone \& M. Cucco. 2000. Distribution of the eastern cottontail Sylvilagus floridanus in the province of Alessandria. Hystrix (n.s.) 11:75-78.

Stamps, J.A., M. Buechner \& V.V. Krishnan. 1987. The effect of edge permeability and habitat geometry on emigration from patches of habitat. Amer. Nat. 129:533-552.

Sullivan, T.P. \& R.A. Moses. 1986. Demographic and feeding responses of a snowshoe hare population to habitat alteration. J. Appl. Ecol. 23:53-63.

Tapper, S.C. \& R.F.W. Barnes. 1986. Influence of farming practice on the ecology of the brown hare (Lepus europaeus). J. Appl. Ecol. 23:39-52.

Terman, C.R. 1966. Population Fluctuations of Peromyscus maniculatus and Other Small Mammals as Revealed by the North American Census of Small Mammals. Amer. Midland Nat. 76:419-426.

Vargas, J. 2000. Distribución, abundancia y hábitat de la liebre endémica Lepus flavigularis (Mammalia: Lagomorpha). Tesis de maestría, Universidad Nacional Autónoma de México.

Vargas, Z. 2001. Valoración de los vertebrados terrestres por huaves y zapotecas del Istmo de Tehuantepec, Oaxaca, México. Tesis de maestría, El Colegio de la Frontera Sur.

Vorhies, C.T. \& W.P. Taylor. 1933. The life histories and ecology of jack rabbits Lepus alleni and Lepus californicus in relation to grazing in Arizona. Univ. Arizona Agricultural Exp. Station. Tech. Bull. 49:471-587.

Zizumbo, V.D. \& P. Colunga. 1982. Los Huaves. La apropiación de los recursos naturales. Universidad Autónoma de Chapingo, México.

Recibido: 8 de marzo de 2007

Aceptado: 26 de octubre de 2007 